Deliberationes tudományos folyóirat

14. évfolyam 1. szám 2021/1, 7-17. oldal

Kézirat beérkezése: 2021.05.21.

Kézirat befogadása: 2021.08.16.

DOI: 10.54230/Delib.2021.1.7
Deliberationes Scienfitic Journal

Vol.14; Ed.No. 1/2021, pages: 7-17

Paper submitted: 25th May 2021

Paper accepted: 16th August 2021

DOI: 10.54230/Delib.2021.1. 7

\title{
A BÜNBÁNAT SZENTSÉGÉNEK AKADÁLYMENTES KISZOLGÁLTATÁSA A HALLÁSSÉRÜLTEK SZÁMÁRA
}

\author{
Bacsa Dávid \\ Pázmány Péter Katolikus Egyetem
}

\begin{abstract}
Absztrakt
Tanulmányomban a megkeresztelt hallássérültek akadálymentesítésének lehetőségeit vizsgálom meg az Egyház gyóntatói gyakorlatában. A hallássérültek saját nyelve a Magyarországon is hivatalos nyelvként rögzített jelnyelv, amin keresztül az egyház szolgálattevője a hallássérülttel személyesen tud kommunikálni és a bünbánat szentségét kiszolgáltatni.

Megvizsgálom azokat az egyházi jogszabályokat, amelyeknél jeltolmács vehető igénybe, valamint azokat a nonverbális jeleket, amelyekkel a szentségkiszolgáltató a hallássérült felkészültségéről meggyőződhet, és a szentség vételére való beleegyezéseként azonosíthat.

Az egyetemes egyházjogi előírások és pápai megnyilatkozások mellett az Egyesült Államok Püspöki Konferenciája által kiadott pasztorális dokumentumot és az abból fakadó részleges jogokat vizsgálom meg a hallássássérültek akadálymentes szentséghez való hozzájutásának bemutatására.

Rávilágítok arra, hogy a megyéspüspök milyen lehetőségekkel rendelkezik a latin és a keleti részleges jog alkotásában, hogy a hallássérültek a keresztségükből fakadó joguk révén akadálymentes módon hozzájussanak és éljenek a bünbánat szentségével.
\end{abstract}

Kulcsszavak: hallássérült, gyónás, akadálymentesítés, nonverbális, jelnyelv, tolmács

\section{GIVING CLEAR SACRAMENT OF PENANCE FOR HEARD OF HEARING PEOPLE}

\author{
Dávid Bacsa \\ Postgraduate Institute of Canon Law, Pázmány Péter Catholic University
}

\begin{abstract}
The focus of this study is on how to remove obstacles for the baptised and hearingimpaired people within the confession sacrament service practice of the Catholic
\end{abstract}


Church. Hearing-impaired citizen's language in Hungary is officially recognized, which allows the priests of the Church to communicate and transfer sacraments of confession through sign-language.

I examine those Church laws, where sign language translator can be employed and those non-verbal signs, on how the sacrament provider can identify the sacrament receiver's preparedness and acceptance.

The apostolic Canon law, papal announcements, and the pastoral documents from United States Bishop Conference and their originated partial laws are examined in order to asses and introduce the hearing-impaired clear sacrament acquisition with supplemented by my own experience.

It is also shown, how ordinary bishops can use these latin and the eastern partial laws in order to comply with hearing-impaired people baptised rights to receive the sacraments of confession the Church in a clear way.

Key Words: hearing-impaired, confession, clear, non-verbal, sign-language, translator

\section{BEVEZETÉS}

A bűnbánat szentségének felvételére a hallássérülteknek nehezebb körülményeik vannak, mint a halló krisztushívőknek. Ugyanakkor az egyházjog lehetőséget biztosít arra, hogy a beszélni nem tudó és néma hallássérültek is részesüljenek a jognak megfelelően a szentségben. A krisztushívő hallássérült verbális szó híján a beleegyező szándékát jelekkel tudja kimutatni, és az egyház szolgálattevőjének ezeket a jeleket kell megfelelően érzékelnie és elfogadnia, hogy megfelelően szolgáltassa ki a bűnbánat szentségét. Az egyházi törvénykönyv a tolmács alatt az idegen beszélt nyelvről való fordítást érti, ugyanakkor a változó pasztorális körülmények olyan helyzeteket teremthetnek, amelyek nincsennek lefedve jogszabályokkal. ${ }^{1}$ Ezért az egyház lehetővé teszi a hallássérültek számára jeltolmács szolgálatát a szentségek felvételekor. Tanulmányomban azokat az egyetemes és részleges jog adta nonverbális jeleket vizsgálom meg, amelyek értelmében a szolgálattevő megbizonyosodhat a hallássérült felkészültségéről és beleegyezéséről a bűnbánat szentségének vételét illetően, valamint azokat az előírásokat, melyeket a közreműködő tolmácsra vonatkoznak. Eddig egyedülálló módon az Egyesült Államok Püspöki Konferenciája adott ki részletes pasztorális iránymutatást (USCCB, 2017) a fogyatékkal élők, köztük a hallássérültek szentségekben való részesüléséről. A pasztorális dokumentum és a hatályos jog mellett a Katolikus Hallássérült Pasztorációban eltöltött tíz éves tapasztalatomat is felhasználom annak megvizsgálásakor, hogy miként részesülhetnek akadálymentes módon a hallássérültek a bünbánat szentségében.

1 Ujházi 2009, 81. 


\section{A HALlásSÉrüLteK}

A 2009. évi CXXV törvény a hallássérült fogalmát úgy fogalmazza meg, mint siket vagy nagyothalló személyt, aki kommunikációja során a magyar jelnyelvet vagy valamely speciális kommunikációs rendszert használja. ${ }^{2}$ A WHO 2020 márciusi adatai szerint a világon közel 466 millió ember szenved halláskárosodásban, és a becslések szerint 2050-re ez a szám eléri a 900 millió főt. ${ }^{3}$ Magyarországon a 2001. évi népszámlálási statisztikák szerint 44679 nagyothalló, valamint 8886 siket, siketnéma és néma él a KHS adatai szerint. ${ }^{4}$ Magyarországon a lakosságnak mintegy $10 \%$-a él valamilyen mértékủ halláskárosulással. Ebbe beletartoznak az enyhe, időskori nagyothallással élő emberek is. Ennek a kb. egymillió hallássérültnek kb. 3-4\%-a, azaz 30-40 000 ember, azonban súlyos fokú nagyothalló, illetve siket. ${ }^{5}$

A hallássérülteket érdekérvényesítésükben összefogó Siketek és Nagyothallók Országos Szövetsége (SINOSZ) a siketséget egy olyan embercsoport létállapotának, adottságának tekinti, amely tagjainak közös vonása, hogy a világot elsődlegesen vizuálisan érzékelik, akiket közös kultúra, hasonló tapasztalatok, viselkedési szokások jellemeznek, és legfőképpen, közös nyelvet, a jelnyelvet használják, amely önazonosságuk szimbóluma is. ${ }^{6}$

Orvosi (audiológiai) értelemben a siketség a hallás (majdnem teljes vagy teljes) hiánya. ${ }^{7}$ Ez a patológiai szemléleten nyugvó meghatározás a siketséget a normálistól való eltérésként, illetőleg hiányként értelmezi, és annak különösen negatív következményeit hangsúlyozza. A nagyothallókkal szemben a siketek tejes csendben élnek, nincs hasznosítható hallásmaradványuk, így hallásuk nem javítható orvosi, technikai eszközökkel. Ök semmilyen hangot nem hallanak, ami miatt a hagyományos kommunikáció lehetetlen számukra. A nagyothallás a hallásromlás mértékétől függően lehet enyhe, közepes vagy súlyos fokú. A nagyothallók legnagyobb része idős korban, fiziológiai elváltozások során szenvedi el a halláskárosodást. ${ }^{8}$ Orvosi szempontból halláscsökkentnek tekintik mindazokat a személyeket, akiknél a halláskárosodás mértéke mindkét fülön a normál $0 \mathrm{~dB}$ alatti értéket mutat. ${ }^{9}$ Egyre többen vannak, akiknek a környezeti ártalmak, vagy például hosszú ideig tartó nagy zajhatás miatt (például hangos zene hallgatása) miatt romlik jelentősen a hallása.

2 2009. évi CXXV. törvény 2. \$.

3 WHO 2020

4 KSH 2014, 12.

5 uo.

6 SINOSZ 2021

7 Ribári 1986, 49.

8 Atkinson \& Hilgard 2005, 154.

9 Ribári 1986, 21. 


\section{IRÁNYMUTATÁS A LELKIPÁSZTOROK SZÁMÁRA}

Az egyházjog legfőbb célja a lelkek üdve (Erdő, 2015, 1752. k.), ezért a törvényhozó az egyes megyéspüspöknek megengedi, hogy az egyházmegyéje pasztorális helyzetét ismerve, illetékességének határain belül mindenkire kötelező szabályokat adjon ki a liturgiával kapcsolatban (Erdő, 2015, 838. k. 4. §). Így a megyéspüspök olyan liturgikus jogszabályokat hozhat, amelynek köszönhetően a hallássérült krisztushívőket akadálymentesítik a bünbánat szentségénél és ezáltal gyakorolhatják a keresztségből eredményező jogaikat és kötelességeket a liturgikus élet területén.

A püspök, aki rábízott egyházban a liturgikus élet irányítója és előmozdítója (Erdő, 2015, 835. k.1. §), köteles gondoskodni területén élő összes krisztushívőről (Erdő, 2015, 383. k.1. $\S)$. Ehhez a munkához a püspökök a lelkipásztorokat és a világi krisztushívőket is segítségül hívhatják, hogy a szentségek felvételére hallássültek is megfelelően felkészüljenek (Erdő, 2015, 843. k.2. §). Azért, hogy ez a segítség valóban hasznos legyen, jelnyelvet értő papok és világiak képzése szükséges. Ugyanakkor nem pusztán a beszélt nyelv jelnyelvbe való átültetésére kell figyelnie az egyháznak, hanem arra, hogy az a jel, és azt kísérő gesztikuláció valóban katolikus hittartalommal bírjon. Ezért nem lehetséges a hallássérültek lelkipásztori szolgálata a katolikus hitet nem ismerő jeltolmács segítségével, mert az illető jeltolmács bár vallásos kifejezést interpretál szó-szerint, de ha nem ismeri annak tartalmát, és így a szentséget illető tudatlanságot (Erdő, 2015, 126. k.), vagy tévedést (Erdő, 2015, 15. k.) idézhet elő a hívőben. A hallássérültek szentségekben való részesülésének joga a keresztségben való részesedésükből fakad (Erdő, 2015, 96. k.), kivéve a házasságot, amely természetjogi eredetű. ${ }^{10}$ A lelkipásztoroknak el kell kerülni annak a látszatát is, hogy a csak a túlnyomó többségben lévő hallókkal foglalkozzon, vagy azt, hogy a jeltolmácsot zavaró tényezőnek tekintse."

A néma, vagy szegényes szókincsű hallássérült akkor veheti magához a szentséget, ha megfelelően kéri azokat, kellőképpen felkészült rájuk, és jogilag nincsenek eltiltva felvételüktől (Erdő, 2015, 843. k.1. §). A lelkipásztor akkor tud megbizonyosodni a hallássérült felkészültségéről, ha beszélt szó híján jelét adja ennek cselekedeteiben, gesztusaiban, hiszen az üzenetnek nem csupán szóbeli jelentése van. A gesztusok üzenete, a jelnyelv egyes szerzők szerint egyidős a beszélt nyelvvel. ${ }^{12} \mathrm{~A}$ hallássérült hívek esetében a nonverbális jelek azok, amik jelzik, hogy a szentségről valóban azt tartja, amit az egyház azokról vall, amelyek lehetnek a jelnyelv „Amen”-je, vagy maga az alázatos testtartás. A szavak nélküli szakrális jelek lehetnek a hallássérült krisztushívő esetében még az imádság gesztusai, az összetett kéz, vagy szentség vételét követő szent csend megtartása, amelyeket a gesztusokat a lelkipásztor a hit és a beleegyezés jeleinek tulajdoníthatja a beszélni nem tudó hallássérült részéről. Ezáltal a gesztusok teológiai és egyházjogi nyelvvé is válnak, hiszen rajta keresztül az egész ember kifejeződhet. ${ }^{13}$

10 Ujházi 2008, 56.

11 Jeng 2009, 40.

12 Akach 2015, 15.

13 v.ö. Csizmadia 2005, 246. 


\section{A TOLMÁCS SZEREPE A SZENTSÉGEK KISZOLgÁLTATÁSÁNÁL}

A jeltolmácsi szolgálatra vonatkozó előírásokat a tolmácsokra vonatkozó hatályos egyházjogi normákból vezethetjük le. Magyarországon 135 fö szerepel a föállású jeltolmácsok országos névjegyzékében. ${ }^{14}$ Elengedhetetlen, hogy a tolmács valóban azt fordítsa a hallássérültnek, amit az egyház a szavak és kifejezések alatt ért. Amenynyiben a tolmács nem katolikus, vagy nem ismeri a katolikus teológiát, könnyen előfordul, hogy nem érti a teológiai fogalmat (pl. kinyilatkoztatás, megtestesülés), vagy olyan lényegi kifejezéseket, mint a felbonthatatlanság, amelyek nem tudása a házasság semmisségét eredményezi. Ez esetben, nem vonatkoztatható a supplet Ecclesia elve (Erdő, 2015, 144. k. 1. §), mert nem ténybeli vagy jogi tévedésről van szó, hanem a közvetlenül a tolmács, közvetetten a lelkipásztor hibájából eredő a hallássérült hívőben beállt tudatlanságról (Erdő, 2015, 126. k.), aminek következtében egyes szentségi cselekmények érvénytelenné válnak. A törvénykönyv a bünbánat (Erdő, 2015, 990. k.) szentségénél kifejezetten említi a tolmács szolgálatának lehetőségét. Amennyiben a jeltolmács személye szentségkiszolgáltatásonként változik, az egyházi jelnyelv kifejezéseinek értelmezése is változhat. ${ }^{15}$ Ezért több szerző és magam szerint is lelkipásztori szempontból az a legideálisabb, ha a szentség kiszolgáltatója tolmács közreműködése nélkül, maga használja a jelnyelvet. ${ }^{16}$

A plébániai munkatársak között lehet olyan személy aki jeltolmács, ez esetben a plébánia gondoskodhat a gyóntatás akadálymentesítéséről. A törvényhozó a szentségkiszolgáltatás érzékeny volta miatt a tolmács igénybevételét a gyónáskor sem a korábbi (v.ö. Codex iuris Canonici, 1951, 903. k. 3. \$.) sem pedig a hatályos törvénykönyvben sem teszi kötelezővé (v.ö. Erdő, 2015, 990. k.).

\section{A BüNBÁNAT SZENTSÉGÉNEK AKADÁLYMENTES FELVÉTELE}

A törvényhozó a gyónót a lelkiismerete alapján kötelezi a gyónásra. A gyónó a lelkiismerete megvizsgálása után méri fel bűneit, amit faj és szám szerint köteles meggyónni az általa választott gyóntatónak (Erdő, 2015, 988. k. 1. §). A gyónás feltétele az értelem használata (Erdő, 2015, 989. k.), ugyanakkor a kisgyermekek és az értelmi fogyatékossággal élö személyek is gyakran tudatában vannak bizonyos mértékig bünös cselekedeteknek, amelyek miatt büntudatot és bánatot érezhetnek (USCCB, 2017). A gyóntatónak figyelembe kell vennie a hallássérült gyónó helyzetét, és azt, hogy kommunikációs nehézsége miatt hogyan írja körül a bűnét. Mindaddig, amíg az egyén képes a bünbánatra, még akkor is, ha nem tudja pontosan leírni a bűnt szavakkal, az illető szentségi feloldozást kaphat (USCCB, 2017).

Az Egyesült Államok Püspöki Karának iránymutatása szerint a nem verbális vagy minimális verbális kommunikációs képességgel rendelkező egyének esetében a bün-

14 A Jelnyelvi Tolmácsok Országos Névjegyzékébe felvett személyekről. (2020, január 8.)

15 Yeng 2009, 40.

16 Robertson 2009, 71. sk. Park, 2009, 31. 
bánatot akkor is el kell fogadnia gyóntatónak, ha ezt a bűnbánatot valamilyen gesztus, nem pedig verbális kifejezés formájában fejezi ki (USCCB, 2017). Sok hallássérült használ technikai készüléket kommunikációs készségük javítására, számukra engedményt tesz a pasztorális dokumentum. A jelentős kommunikációs zavarokkal küzdő hívek számára megengedhető, hogy gyónásaikat kommunikációs rendszer segítségével tegyék meg (USCCB, 2017).

Ha a gyóntató nem ismeri a jelnyelvet, igénybe veheti, vagy megengedheti a tolmács szolgálatát (Erdő, 2015, 990. k.). A tolmácsot titoktartási kötelezettség köti (Erdő, 2015, 983. k.2. §), aki, ha azt megszegi, megfelelő büntetéssel büntethető (Erdő, 2015, 1388. k.2. §). Célszerủ azonban, ha a hallássérült olyan gyóntatóhoz fordul, aki legalább érti a jelnyelvet, vagy a gesztikulációkat, és abból helyes ítéletet tud alkotni. A bünök jellegének és számának megfelelően, ugyanakkor a hallássérült gyónó helyzetének figyelembevételével, a gyóntató szabjon ki üdvös és megfelelő elégtételt, ezt a gyónó személyesen köteles és képes elvégezni (Erdő, 2015, 981. k.). Ha a gyóntató nem kételkedik a gyónó felkészültségében, és az a feloldozást kéri, a feloldozást ne tagadja meg és ne is halassza el (Erdő, 2015, 980. k.).

A hallássérültek számára is biztosítani kell a személyes bűnbevallás lehetősségét. Ha jelnyelvet ismerő pap, vagy tolmács nem áll rendelkezésre, meg kell engedni a hallássérült számára, hogy írásban végezhessék el a gyónásukat, vagy megfelelő hordozható elektronikus kommunikációs eszköz használatával, amely oda-vissza átadható a bünbánó és a gyóntató között. Az írott vagy digitális anyagokat vissza kell adni a bűnbánónak, és megfelelően meg kell semmisíteni vagy törölni kell (USCCB, 2017). Erre példa a Romuald P. Zantua atya által kialakított gyakorlat, amelyben a chat-szobához hasonló program két, kábellel csatlakoztatott laptopra van telepítve. A bűnvallomás és az elégtétel megadása írásban történik. Az eszközt csak gyónás alkalmából használják, és az internetkapcsolat le van tiltva a titoktartás biztosítása érdekében. ${ }^{17}$ A gyónás pecsétjét (sigillum sacramentale) védve a Hittani Kongregáció 1988. 09. 23-i határozatában (Congregatio pro Doctrina Fidei 1367/1988) önmagától beálló kiközösítéssel sújtja azokat, akik a technikai eszközzel mások vagy a saját maguk által felvett bünvallomást nyilvánosságra hozzák. Az Egyesült Államok Püspöki Konferenciájának részleges törvénye a gyónás felvételéről nem látszik ellentétesnek a Hittani Kongregáció állásfoglalásával, mert a felvételeket a gyónónak vagy a gyóntatónak a gyónást követően minél hamarabb meg kell semmisítenie.

A gyóntatás helye a latin szertartásban a templom vagy a kápolna, ugyanakkor a törvényhozó megadja a lehetőséget olyan gyóntatóhelység kialakítására, amelyben a gyónót és a gyóntatót rács választja el egymástól (Erdő, 2015, 964. k. 1-2. \$\$). A gyóntatóhelység kialakítására vonatkozó szabályokat a helyi püspöki konferencia adhatja ki, amely tekintettel lehet a hallássérültekre. Amennyiben a hallássérült tolmácsot visz magával a gyónásra, előzetesen értesítse a lelkipásztort, hogy a szentség felvétele

17 Vargas 2014 
ne gyóntatószékben, hanem tágasabb helyen, pl. gyóntatószobában kerülhessen sor. ${ }^{18}$ A gyóntatórács a hatodik parancs ellen elkövetett bün gyanújától óvja meg a gyóntatót és a gyónót, ugyanakkor a hallássérültek gyóntatása esetén szükséges a kéz és a gesztikuláció akadálytalan látása. Tomás Rincón-Pérez szerint a gyóntató az, aki legjobban meg tudja ítélni, hogy van-e megfelelő ok, tekintetbe véve a személyi körülményeket, ahol a szentségkiszolgáltatás megfelelő módon kiszolgáltatható, akár olyan helységben ahol nincs gyóntatórács. ${ }^{19}$ Amennyiben a szentgyónás kihallatszana a gyóntatóhelységböl, a fültanúkra ugyanúgy vonatkozik a titoktartási kötelezettség (v.ö. Erdő, 2015, 983. k. 2 §).

\section{AKADÁLYMENTES KELETI ÉS RÍTUSKöZI KISZOLGÁLTATÁS}

A hallássérültek között nemcsak latin, hanem keleti katolikus rítusú krisztushívők is lehetnek, akik szükség esetén latin szertartású szentségkiszolgáltatóhoz is fordulhatnak. ${ }^{20} \mathrm{~A}$ keleti egyházak hagyományában nem található meg az automatikus (latae sententiae) büntetés, helyette a Keleti Egyházak Törvénykönyve (Rihmer, 2012) a fenntartott bünök fogalmát ismeri, ${ }^{21}$ amely szerint Apostoli Szentszéknek és az ordináriusnak ${ }^{22}$ van fenntartva bizonyos bünök alóli feloldozás lehetösége. Ennek pedagógiai és lelkipásztori céljai vannak, miszerint a gyónóban azt tudatosítják, hogy a bủne olyan súlyos, hogy magának az ordináriusnak kell őt feloldoznia. A gyakorlatban, ha akadályba ütközik, a megyéspüspökhöz való elmenetel, a gyóntatópap a megyéspüspöktől kér egy egyszeri engedélyt a „fenntartott” bűn feloldozására, és megkéri a gyónót, hogy egy meghatározott időpontban jöjjön vissza, hogy az engedély birtokában a gyóntatópap feloldozza. A gyóntatópap kérje meg a gyónót, hogy ebben a várakozási időben továbbra is gyakorolja bűnbánatot. A törvényhozó a keleti törvénykönyvben szintén lehetőséget ad a tolmács szolgálatának igénybevételére, ugyanazokkal a feltételekkel, mint a latinban hozott (Rihmer 2012, 733. k. 2. §).

Elöfordulhat olyan eset, amikor a keleti rítusú hallássérült hívő gyónna latin rítusú papnál, olyan bünt, ami a saját egyházában a püspöknek van fenntartva, de a latin papnak joghatósága (facultas) ${ }^{23}$ van rá, pusztán azért, mert a latin szertartású szolgálattevő ismeri a jelnyelvet. Célszerü, hogy a hívő a saját rítusú papnál gyónjon. Azonban a jelnyelvet ismerő keleti szentségkiszolgáltató hiányában érvényesen gyón latin papnál a keleti rítusú hallássérült hívő. Ugyanakkor látszatát is el kell kerülni annak, hogy valaki azért gyón latin rítusú papnál keletiként, mert a latinnál enyhébb-

18 Calvi 1999, 225-232.

19 Rincón-Pérez 1999, 227-257.

20 A témáról bővebben 1. Szabó, (2012). 211-261.

21 Erdő 2002, 7.

$22 \mathrm{Az}$ ordinárius név alatt értjük az egyházjogban a pápát, a megyéspüspököket, és azokat akik még csak ideiglenesen is valamely részegyház vagy azzal egyenrangú közösség élén állnak, valamint azokat akiknek ezekben a közösségekben általános végrehajtói hatalommal bírnak. Erdő 2014, 156.

23 1. Keppinger 2013, 91-99. 
nek tűnik a gyónási fegyelem. A törvényhozó a keleti rítusúak számára a gyóntatás helyszínéül a templomot jelöli meg (Rihmer 2012, 736. k. 1. \$), nem beszél a latinhoz hasonlóan zárt gyóntatóhelységről vagy ráccsal való elválasztásról (v.ö. (Erdő, 2015, 964. k. 2. §). Ezért a keleti rítusú akadálymentes szentségkiszolgáltatás szabályzására a keleti megyéspüspök önálló intézkedéseket hozhat, így gyóntatószobák kialakítását is lehetővé teheti a templomban.

\section{BEFEJEZÉS}

Az egyház arra törekedik, hogy a hívek számára lehetővé tegye a liturgiában a tudatos és cselekvő részvételt, amelyet magának a liturgiának a természete megkíván, és amelyre a híveknek a saját helyzetük révén joguk van, és amely egyúttal kötelességük is (RMÁR, 2014). A hallássérült hívek tolmács segítségével vagy a nonverbális jelek használatával megfelelő módon tudnak a szentségekben részesülni, feltéve ha a szolgálattevő a jeleket megérti. Ezért kell a lelkipásztoroknak legalább olyan módon ismerniük a hallássérültek gesztusait, hogy igazságos ítéletet hozzanak. Ennek a megvalósítására a törvényhozó nem kíván az egyetemes törvényen kívül a részleges törvényeket hozni, hanem azokat a helyi viszonyokat ismerő helyi püspöki konferenciákra és megyéspüspökökre bízza (RMÁR, 2014).

A liturgikus jog a megyéspüspököt kötelezi arra, hogy egyházmegyéjében elmélyítse és irányítsa a liturgikus életet (RMÁR, 2014). Amikor a lelkipásztorok a megyéspüspöktől kapott a beleegyezés jeleiről szóló részleges törvényeket átültetik a hallássérültek lelkipásztori gondozásának gyakorlatába, mindig figyelembe kell venniük a más fogyatékkal élők ellátásáról szóló párhuzamos helyeket, a törvény célját, körülményeit, valamint a törvényhozó szándékát (Erdő, 2015, 17. k.).

A II. Vatikáni Zsinat Optatam totius kezdetű papnevelésről szóló határozata az újabb társadalmi körülmények miatt szorgalmazza a papság továbbképzését. A már felszentelt papok nem hagyhatják abba a teológiai és a lelkipásztori segédtudományokban való elmélyülésüket (OT, 22.). Ajánlatos, hogy azok a lelkipásztorok akiknek a területén hallássérült krisztushívők élnek, alapvető ismeretekkel rendelkezzenek a hallássérültek nevelésével foglalkozó tudomány, a szurdopedagógia ismeretben, valamint a jelnyelv elsajátításában. Ezzel segítve elő, hogy a hallássérültek is gyakorolják a megkeresztelésükből származó jogaikat a bünbánat szentségét illetően (v.ö. Erdő, 2015, 213 k.).

Kapcsolattartó szerző:

Corresponding author:

Bacsa Dávid

Dávid Bacsa

Pázmány Péter Katolikus Egyetem

Kánonjogi Doktori Iskola

1088 Budapest

Szentkirályi u. 28-30.

david.bacsa91@gmail.com

Postgraduate Institute of Canon Law

Pázmány Péter Catholic University

Szentkirályi str. 28-30.

1088 Budapest, Hungary david.bacsa91@gmail.com 


\section{IRODALOMJEGYZÉK:}

Az igazságosság és béke pápai tanácsa. (2007). Az Egyház társadalmi tanításának kompendiuma. Szent István Társulat. https://www.vatican.va/roman_curia/ pontifical_councils/justpeace/documents/rc_pc_justpeace_doc_20060526_ compendio-dott-soc_hu.html

Akach, O. (2015). Liturgy for the deaf congregation: Why a dedicated worship service. University of Free State.

A Katolikus Egyház Katekizmusa. (2009). Szent István Társulat. https://archiv. katolikus.hu/kek/

A klérus kongregációja. (1998). A katekézis általános direktóriuma. Szent István Társulat. https://regi.katolikus.hu/konyvtar.php?h=142

Atkinson, C. R., \& Hilgard E. (2005). Pszichológia, Osiris Kiadó.

Bánk, J. (1963). Kánoni jog II. Szent István Társulat.

Budapest Főváros Kormányhivatala. (2020, január 8). A Jelnyelvi Tolmácsok Országos Névjegyzékébe felvett személyekröl. https://www.kormanyhivatal.hu/ download/3/ad/76000/Jelnyelvi\%20Tolm\%C3\%A1csok\%20Orsz\%C3\%A1gos\%20 N\%C3\%A9vjegyz\%C3\%A9ke.pdf

Calvi, M. (1999). Lugo e sede per la celebrazione del cacramento della penitenza. In Miragoli, E. (Ed.). (1999). Il sacramento della penitenza Il ministero del confessore: indicationi canoniche e pastorali. (225-232). Ancora.

Codex iuris canonici. (1951). Typis Polyglottis Vaticanis,

Congregatio pro Doctrina Fidei (1988). Urbis et orbis decretum. AAS 80. https://www. vatican.va/archive/aas/documents/AAS-80-1988-ocr.pdf

Cuschieri, A. (1992). The sacrament of Reconciliation. A theological and canonical treatise. Lanham.

Csizmadia, I. (2005) A pap szerepének hangsúlyváltozásai a bünbánat szentségének liturgiatörténetében, Egri Hittudományi Főiskola.

Dennis, C. (2005). A tolmácsolás szociolingvisztikai modellje. Magyar Jelnyelvi Programiroda.

Diós I. (Ed.). (2007). A II. Vatikáni Zsinat dokumentumai. Szent István Társulat.

Erdö, P. (Ed.). (2015). Az Egyházi Törvénykönyv. A Codex Iuris Canonici hivatalos latin szövege magyar fordítással és magyarázattal. Szent István Társulat.

Erdő, P. (2002). Rítusközi (egyházközi) gyóntatási fegyelem a katolikus egyházban. Kánonjog, 2002(4)

Erdő, P. (2014). Egyházjog. Szent István Társulat.

Henger, K. \& Kollár, É. (2005). A jelnyelvi tolmácsolás etikája. Magyar Jelnyelvi Programiroda.

Hervada, J., \& Lombardia, P. (1973). El derecho del Pueblo de Dios. Haica un sistema de derecho canonico 3/1. Derecho Matrimonial. Ediciones Universidad de Navarra. 
II. János Pál (1981). AdhortatioapostolicaFamiliarisconsortio, AAS 74. https://www. vatican.va/archive/aas/documents/AAS-74-1982-ocr.pdf

Keppinger, B. (2013). Adalékok a „facultas” kifejezés jelentéséhez és használatához a II. Vatikáni Zsinat dokumentumaiban. Kánonjog, 2013(15)

Központi Statisztikai Hivatal. (2014). A 2011. évi népszámlálás https://www.ksh.hu/ docs/hun/xftp/idoszaki/nepsz2011/nepsz_11_2011.pdf

Lancz, E., \& Berbeco, S. (2004). A magyar jelnyelv szótára. Siketek és Nagyothallók Országos Szövetsége.

Magyar Országgyủlés. (2009). 2009. évi CXXV. törvény. https://net.jogtar.hu/ jogszabaly?docid=a0900125.tv

Park, M. S. (2009). Deaf cultural and deaf church: consideration for pastoral ministry. Gallaudet University Press.

https://www.scd.org/sites/default/files/2017-07/deaf-culture-deaf-church.pdf

Ribári O. (1986). Fül-Orr-Gégészet, Medicina Könyvkiadó.

Rincón-Pérez, T. (1999) Los derechos de los fieles y el sacramento de la penitencia (a propósito de dos notas recientes del pcitl). Ius Canonicum 1999(39)

Rihmer, Z. (Ed.). (2012). A Keleti kódex - A keleti egyházak kánonjainak törvénykönyve. Szent Atanáz Görög Katolikus Hittudományi Főiskola. https://www.nyirgorkat.hu/ mediatar/dokumentumok/0001_Keleti_Kodex.pdf

Robertson, I. (2010). "Duc in altum:” A Model for Education in Ministry. Ephphatha! The Deaf Person in the Life of the Church, 2010(1)

https://www.humandevelopment.va/content/dam/sviluppoumano/pubblicazionidocumenti/archivio/salute/dolentium-hominum-en-1-72/DH_73_en.pdf

Szabó, P. (2012.). A keleti egyházak Szentségi joga. Szent Atanáz Görögkatolikus Hittudományi Főiskola.

SINOSZ. (2021). Siketség és jelnyelv.

Https://sinosz.hu/siketseg-es-jelnyelv/ Utoljára ellenőrizve: 2020. 11. 25.

United State Conference of Catholic Bishops (2017, june 15). "Guidelines for the Celebration of the Sacraments with Persons with Disabilities.". 70-71. https://www. usccb.org/committees/divine-worship/policies/guidelines-sacraments-personswith-disabilities

Ujházi, L. (2008). Gyermekek keresztelése és a keresztség „elhalasztásának” kérdése a hatályos jogban. Kánonjog, 2008(10)

Ujházi, L. (2009). A joghézag feloldásának lehetőségei az egyház hatályos jogában (CIC 19. kán). Kánonjog, 2009(11)

Vargas G. A. (2014). Hearing Loss and the Confessional.

https://www.audicus.com/hearing-loss-and-the-confessional/

Vinson J. (2015). The sacrament of penance: pastoral and inter-ritual difficulties regarding reserved sins and Latae Sententiae cansures (Part 1). Iustitia, 2015(6)

WHO. (2020). Deafness and hearing loss. 
Https://www.who.int/news-room/fact-sheets/detail/deafness-and-hearing-loss Utoljára ellenőrizve: 2021. 08. 04.

Yeng, P. J. (2010). The Challenges of Deaf Catholics in the Life of the Church. Ephphatha! The Deaf Person in the Life of the Church, 2010(1)

https://www.humandevelopment.va/content/dam/sviluppoumano/pubblicazionidocumenti/archivio/salute/dolentium-hominum-en-1-72/DH_73_en.pdf 